\title{
Application of Chemical Oxidation Using Sodium Perioadate in the Production of Activated Carbon
}

\section{Ammar A. Hamdoon Omar M. Ramadhan Khalid A. Aweed Department of Chemistry, College of Education Mosul University, Mosul - Iraq}

\author{
Received \\ Accepted \\ 28/2/2004 \\ 20/10/2004
}

\begin{abstract}
الخلاصة
يتضمن البحث تحضير كاربون منشط من المواد القيرية و الاسفلتية عن طريق اجـر اء

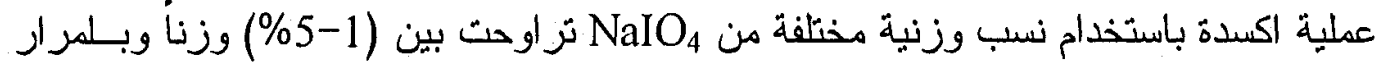

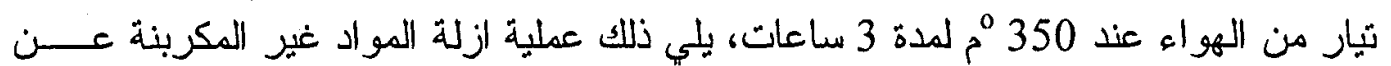
طريق اجراء عملية تقطير فر اغي. بتم تحضير الكاربون المنشط عن طريق مفاعلة مخلفات التقطير الفر اغـــي (للمــادة

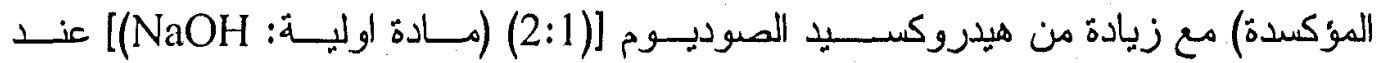

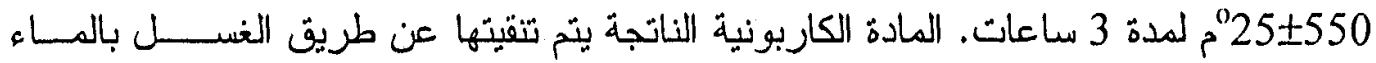

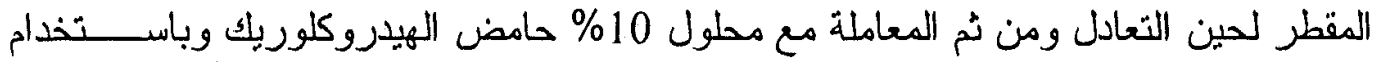

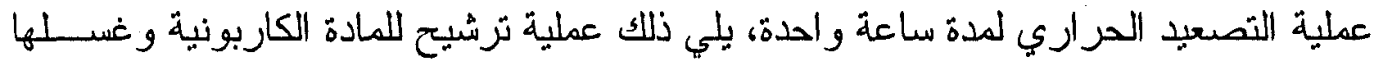

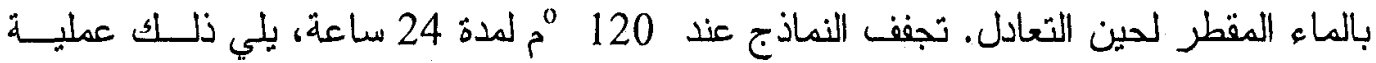

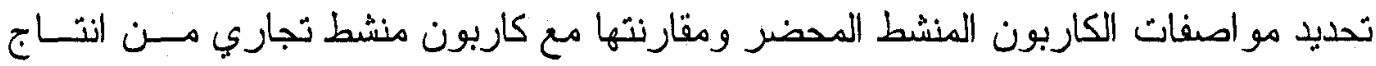

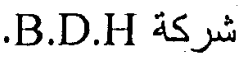

\section{ABSTRACT}

In this work activated carbon of a good quality prepared using oxidation condensation process. The oxidation of the asphaltic materials was conducted using several percentage of $\mathrm{NaIO} 4$ and in the presence of a stream of air or oxygen. The reaction mixture was heated at $350^{\circ} \mathrm{C}$ for $3 \mathrm{hrs}$, this followed by removal of uncarbonized materials by heating under reduced pressure. The condensation of the fractions obtained is expected to recombine or re-react to give a high carbon content. The carbonization and activation was conducted at $550 \pm 25^{\circ} \mathrm{C}$ for $3 \mathrm{hrs}$. by mixing with $\mathrm{NaOH}$, and the ratio of the feedstock to $\mathrm{NaOH}(1: 2)$. After the carbonization was completed, the reaction mixture was subjected to purification by treatment with $10 \% \mathrm{HCl}$ and distilled water till it gives neutral test to the litmus paper. The samples were dried at $120^{\circ} \mathrm{C}$ for $24 \mathrm{hr}$. and its physical properties were determined.

The research work indicated that a good quality activated carbon was obtained when the oxidation of sample was conducted using $3 \%$ 
Where:

$\mathrm{m}=$ is the weight of the activated carbon in grams

$\mathrm{X}=\mathrm{A}-[2.2 \mathrm{Bx} \mathrm{ml}$ of thiosulfate solution used $]$

$A=N_{1} \times 1269.0$

$\mathrm{B}=\mathrm{N}_{2} \times 126.93$

$\mathrm{N}_{1}$ = normality of iodine solution.

$\mathrm{N}_{2}$ = normality of sodium thiosulfate solution.

$\mathrm{D}=$ correction factor.

\section{RESULTS AND DISCUSSION}

Active carbon is a very important industrial product due to its uses in various aspect of modern civilization. Its mainly produced from highly content carbon feedstock. The production from the industrial point of view available to the consumer will be protected by secrets and patents owned to some chemical companies in the world.

In this work we aimed to produce activated carbon of a good quality by carbonizing the materials through oxidation condensation process which employed $\mathrm{NaIO}_{4}$ in different percentage and in the presence of stream of air at about $350^{\circ} \mathrm{C}$ for experimental period of 3 hrs. The oxidation process whether proceed through radical or ionic mechanism is designed to introduce oxygen in the structure and to form oxygenated linkage or carbon-oxygen linkage, which will lead to increase the viscosity and density of the product through condensation processes and finally increase the molecular weight, asphaltene content, resin content and carbon content. Also we aimed in this work to modify the surface of the activated carbon by introducing oxygen functional group ( $\mathrm{CO}, \mathrm{COO}, \mathrm{O}-\mathrm{O}$ : etc.). In our method of preparing the activated carbon the oxidized materials were mixed with twice its weight of $\mathrm{NaOH}$ and homogenized with little water. The product purified by using $10 \% \mathrm{HCl}$. The product washed with distilled water and dried at $120^{\circ} \mathrm{C}$ for $24 \mathrm{hr}$. The results of the study are given in the table. The results in the table employing $\mathrm{NaIO}_{4}$ as in oxidizing agent in the presence oxygen from air indicated that the ash content of all the produced samples content which is acceptable from the commercial point of view. The density of activated carbons as comparable to that of the B.D.H commercial grade, while humidity content is slightly higher than the commercial one and this can be reduced by elevating the temperature to $250^{\circ} \mathrm{C}$ without exposure to the air to get little loss in the carbon. However, measuring internal porous in the form of iodine number in $\mathrm{mg} / \mathrm{gm}$ indicated that the iodine number when $3 \% \mathrm{NaIO}_{4}$ was used is better than the commercial sample by almost $35 \%$. On the other hand investigated the external porous which is termed as macro pores in term of the of adsorption methylene blue show almost 
2.5 time greater than the commercial one (225/90). When the amount of feedstock is constant, contact time, carbonizing period and other reaction parameter are kept constant; it is found that $3 \% \mathrm{NaIO}_{4}$ is the most powerful amount in the catalysis which may indicate that the little amount (below 3\%) is not sufficient for the oxidation and recombination of the fragments. On the other hand increasing the amount above $3 \%$ may result in stable oxygenated species which dose not react to increase the carbon content therefore, the optimum amount for catalyst is $3 \%$.

In this regard a new research work required to help the work of the oxidizing agent either with Lewis acids or any enhancer is under investigation in the next papers.

Table

Physical Properties of The Prepared Activated Carbon

\begin{tabular}{|c|c|c|c|c|c|c|}
\hline Sample & NaIO $_{4}^{*} \%$ & $\begin{array}{c}\text { Density } \\
\mathbf{g m} / \mathbf{c m}^{3}\end{array}$ & Ash \% & Humidity \% & $\begin{array}{c}\text { Iodine } \\
\text { number } \\
\mathbf{m g} / \mathbf{g m}\end{array}$ & $\begin{array}{c}\text { Methylene } \\
\text { Bluc } \\
\mathbf{m g} / \mathbf{g m}\end{array}$ \\
\hline $1^{* *}$ & 0 & 0.390 & 1.000 & 1.100 & 600 & 50 \\
\hline 2 & 1 & 0.352 & 3.321 & 1.601 & 650 & 158 \\
\hline 3 & 2 & 0.346 & 3.225 & 1.891 & 750 & 163 \\
\hline 4 & 3 & 0.340 & 3.671 & 1.621 & 1125 & 225 \\
\hline 5 & 4 & 0.328 & 3.661 & 1.001 & 652 & 102 \\
\hline 6 & 5 & 0.382 & 3.600 & 1.802 & 600 & 95 \\
\hline $\begin{array}{l}\text { Commercial } \\
\text { from B.D.H }\end{array}$ & & 0.345 & 3.200 & 0.800 & 908 & 90 \\
\hline
\end{tabular}

*\% By Weight

** Without catalyst 


\section{REFERENCES}

1. Abbasi, W.A. ; streat, M., Separation Science and Technology, 29(9):1217-1230 (1994).

2. El-Nabarawy, T. H., Mostafa, M.R. and Youssef, A.M., Absorption Science and Technology, 15(1):59-68 (1997).

3. Saleem, M., Afzal, M., Qadder, R. and Manif, J., Separation Science and Technology, 27(2):239-253 (1992).

4. Qadder, R. and Manif, J., Radiochimica Acta,65:259-263 (1994).

5. Qadder, R: and Hanif, J., J. Radio anol. NuCl. Chem., Letters, 165(4) :243-253 (1992).

6. Mostafa, M.R., Adsorption Science and Technology, 15(8):551-557 (1997).

7. Teng, H., and Lin, H.C., AICHE Journal, 44(5):1170-117 (1998).

8. Parkash, S., Chemistry and Industry, pp. 445-451 (1974).

9. Shreve, R.N., Joseph, A., Brink and Brink, Jr., "Chemical Process Industries", $4^{\text {th }}$ ed., Mc Graw-Hill Book Company, (1976).

10.Corten, V.A., and Weisses, D.E., Revs, Pure and Appl. Chem. Vol.7, p.69 (1957).

11.Ceren, K. and Meral, E., Ege University Institute of Nuclear Sciences, 35100, Bornova, Izmir Turkey (2000).

12.O'Grady, T.M. and Wennerberg, A.N., ACS Symposium Series 303, Publ. ACS, Washington D.C. U.S.A, pp.302-309 (1984).

13.Jeyaseelan, S. and Chen, X.G., CSE Research Bulletin, No.13, Jan. pp.1-3 (2000).

14.Schwichardi M., Johann T. , Schmidt W. and Schuth F., Tatranske Matliare, Slovak Republic, pp.26-30, May (2003).

15.Alvim, F.M., Fuel, 67(9):1237-1241, Sep. (1988).

16. Yamaguchi, T., Fuel, Vol.59, pp.444-445, June (1980).

17. Yu. Qiao, (Lushan Forestry Center). Faming Zhuanli Shening Gongkai Shuomingshu CN88, 102,426(CL.CO/B31/12) 02 Nov., (1988), Appl. 23, Apr., (1989), 6pp.C.A. 157105a 110, 18, (1989).

18.Teng, H.S. and Weng, T.C., Microporous and Mesoporous Materials, 50(1):53-60, Dec. (2001).

19.Kobayashi, S. , Yuan U., Kuragan K. , Gami K. , Takiguchi Y. and Onoe K., Active Carbon Supercondenser, March, 4 (2003).

20.ASTM D2854, 70 Standard Test Method for Apparent Density of Activated Carbon.

21.ASTM D2866-70, "Total Ash Content of Activated Carbon", Extracts were Reprinted with Permission from Annual Book of ASTM Standard Copyright ASTM Race Street, (1916). 
22.ISO, 5.62-1981, "Determination of Volatile Matter Content of Hard Coal and Coke", The Full Text Can be Obtained From ISO Central Secretarial Cose Postable 5G, CH-1211: Genera 20 or from any ISO Member.

23.Test Methods for Activated Carbon Rosterbau Int. Engineering GMBH, W. Germany Devtschos Arzneibuch $6^{\text {th }}$ Ed.

24.AWWA Standard for Granular Activated Carbon, B604-74, Sec. Approved by J. The American Water Works Association Board of Directors on Jan. 28, (1974). 